\title{
Identifying the potential of some heavy metals toxicity in urban and peri-urban cropping systems in Sierra Leone
}

\author{
Abdul Rahman Conteh ${ }^{*}$, Alusaine Edward Samura, Emmanuel Hinckley, \\ Osman Nabay and Mohamed Saimah Kamara
}

\author{
Njala Agricultural Research Centre, Sierra Leone Agricultural Research Institute (SLARI), Sierra Leone. \\ ${ }^{*}$ Corresponding author. Email: Email: contehar@yahoo.com. Tel: 232-79 501135.
}

\begin{abstract}
Copyright (? 2017 Ekele. This article remains permanently open access under the terms of the Creative Commons Attribution License 4.0, which
\end{abstract} permits unrestricted use, distribution, and reproduction in any medium, provided the original work is properly cited.

Received 20th August, 2017; Accepted 11th September, 2017

\begin{abstract}
As an essential coping strategy for providing the vital augmentation of food stocks in urban centers, there has been a considerable expansion of urban and peri-urban agriculture in Sierra Leone since the end of the civil war in 2002. In many of these urban and peri-urban cropping sites, sources of water are usually polluted by urban wastes posing potential risk of heavy metal toxicity. This study was carried out to determine the risks associated with heavy metal contamination in urban and peri-urban cropping systems in Sierra Leone. Soil and plant samples were collected from 72 sites from the largest and second largest cities, Freetown and Bo. The samples were analyzed for $\mathrm{Zn}, \mathrm{Cu}, \mathrm{Cr}$, $\mathrm{Ni}, \mathrm{Pb}$ and $\mathrm{Cd}$, and the results compared to established reference values. Heavy metals were detected across all sites, with highest concentrations found in Freetown. Values obtained were mostly below the reference values for both soil and plant samples. Some mild risk of toxicity by $\mathrm{Cd}$ was observed in densely populated areas of Freetown, but this was not reflected in the plant uptake of $\mathrm{Cd}$. In general, the risk posed by heavy metals in the urban centers of Sierra Leone is minimal, but measures should be taken to prevent further increase in heavy metal concentration in urban cropping sites.
\end{abstract}

Key words: Heavy metal, soil contamination, urban agriculture, urban garbage.

\section{INTRODUCTION}

Sierra Leone experienced a civil conflict between 1991 and 2002, because of which many people fled to the urban centers, especially the capital city, Freetown. Due to urban migration and natural population growth (UNFPA, 2007), Sierra Leone's cities have been growing rapidly. The increase in population has been so fast that the delivery of basic services, such as water supply, sanitation and waste removal cannot keep up. At the end of Sierra Leone's ten-year civil war in 2002, a significant proportion of the population who had sought refuge in the urban centers decided to remain in these urban centers in search of jobs with the hope of improving their living conditions (Kanu et al., 2009). This resulted in an unprecedented increase in urban populations in Sierra Leone creating high pressures on food supplies. The bulk of these refugees were rural migrants with a strong agricultural background. In the absence of regular employment, many of these migrants entered into urban and peri-urban agriculture (CFF, 2008), cultivating leafy vegetables and marketing fruits and vegetables within and near the urban centers, especially in Freetown, the capital city and in Bo, the second largest city.

During and after this period, urban farming became one of the survival strategies adopted by the urban population of Freetown, and has significantly contributed to the food supply in the city. Consequently, local and international non-governmental organizations initiated urban and periurban agriculture programmes in Freetown. Since 2005, in order to mitigate the impending food crisis, the Ministry of Agriculture in Sierra Leone has been promoting urban 
farming under the United Nations Food and Agriculture Organization's Special Project for Food Security (FAO, 2008a). This caused an expansion of urban and periurban agriculture as an essential coping strategy for providing the vital augmentation of food stocks (Kanu et al., 2009). Urban agriculture is now increasingly being recognized as a reliable coping mechanism for redressing food shortages and gaining employment in the urban centers of Sierra Leone.

Urban and peri-urban agriculture is an industry located within (intra-urban) or on the fringes (peri-urban) of a town, a city or a metropolis, which grows and raises, processes and distributes a diversity of agriculture products, using largely human, land and water resources, products and services found in and around that urban area (FAO, 2008b). In addition to supplementing rural agriculture in food supply, urban agriculture creates an avenue for recycling readily available urban organic wastes. However, despite the potential benefits of urban agriculture (Cofie, 2003), there are also potential risks such as heavy metal toxicities (USDA, 2003). The application of numerous bio-solids (livestock manures, composts, and municipal sewage sludge) to land inadvertently leads to the accumulation of heavy metals such as Cadmium (Cd), (Chromium) (Cr), Copper (Cu), Lead $(\mathrm{Pb})$, Nickel (Ni), and Zinc ( $\mathrm{Zn})$ in the soil (Farid et al., 2015). Under certain conditions, metals added to soils in applications of biosolids can be leached downwards through the soil profile and can have the potential to contaminate groundwater. Recent studies on some New Zealand soils treated with biosolids have shown increased concentrations of $\mathrm{Cd}, \mathrm{Ni}$, and $\mathrm{Zn}$ in drainage leachates (Wuana and Okieimen, 2011).

Plants grown in polluted environment can accumulate heavy metals at high concentration causing serious risk to human health when consumed (Naser et al., 2011). Traditional treatments for metal contamination in soils are expensive and cost prohibitive when large areas of soil are contaminated (Tella et al., 2013; Jiang et al., 2014). Moreover, heavy metals are toxic because they tend to bio-accumulate in plants and animals, bio-concentrate in the food chain and attack specific organs in the body (Chatterjee and Chatterjee, 2000; Akinola et al., 2008). Vegetables, especially leafy vegetables, accumulate higher amounts of heavy metals. Roots and leaves of herbaceous plants retain higher concentration of heavy metal than stems and fruits (Yargholi and Azimi, 2008).

There has been a plethora of studies on heavy metal concentration and toxicity in soil, and the literature is abound with such studies (McLaughlin et al., 2000: Mecray et al., 2001; Crusberg et al., 2004; Ghosh and Singh, 2005; Isa and Jimoh, 2013; Chiroma et al., 2014). However, similar studies have not been carried out extensively in the sub-Sahara Africa region. Some studies related to heavy metal concentration have been reported in Nigeria (Ogbonna et al., 2009; Fagbote and Olanipekun, 2010; Opaluwa et al., 2012; Chibuike and
Obiora, 2014) and in Ghana (Ampofo and Awortwe, 2017). Similar studies carried out in Sierra Leone are rare. As a country recovering from the twin effects of a civil war (1991 to 2002) and the deadly Ebola outbreak (2014 to 2015), understanding the occurrence and concentrations of potentially toxic heavy metals in urban agricultural systems in Sierra Leone will provide a very useful guide for future agricultural and land-use planning and the development of timely intervention strategies. Thus, this study was carried out to determine the risks associated with heavy metal contamination in urban and peri-urban cropping systems in Sierra Leone, with particular reference to the largest and second largest cities of Freetown and Bo.

\section{MATERIALS AND METHODS}

\section{Study area}

Sierra Leone is in the lowland humid tropics on the west coast of Africa, between latitude $6^{\circ} 55^{\prime} \mathrm{N}$ and $10^{\circ} 00^{\prime} \mathrm{N}$ and longitude $10^{\circ} 16^{\prime} \mathrm{W}$ and $13^{\circ} 18^{\prime} \mathrm{W}$. The country covers a total area of 7.2 million hectares, of which 5.4 million hectares are arable (WFP, 2015). Approximately 56.0 percent of the land is less than 150 meters above sea level. Agriculture, forestry and fisheries are the mainstay of the economy in terms of employment, engaging about 65 percent of the labour force, mostly working in subsistence agriculture (ILO, 2015). The climate is tropical with two pronounced seasons: an intense rainy season from May to October and a dry season from November to April. Annual precipitation ranged between 3,000 and 5,000 millimeters. The national temperatures generally range from an average of 24.1 to $28.3^{\circ} \mathrm{C}$, except in the Harmattan period, between November and February, when it can drop to below $20^{\circ} \mathrm{C}$ at night. The soils are generally poor, acidic, rich in iron oxide and prone to heavy leaching (Rhodes, 1988; Amara Denis et al., 2013).

In collaboration with the Ministry of Agriculture, Forestry and Food security (MAFFS) in Sierra Leone, existing farmer-based organisations and other emerging groups were identified and sensitized on the project with the aim of forming a platform of urban and peri urban farmers in Bo (southern province) and in Freetown (Capital city, western area). Sites were also identified for the assessment of risk of contamination by biotic and abiotic factors and geo-referenced, taking note of the location, chiefdom, longitude, latitude and elevation. Seventy-two sites from the largest and second largest cities, Freetown and Bo, were identified (Figure 1) from which soil and plant samples were collected.

\section{Sample collection and preparation}

The study was carried out between June and August 


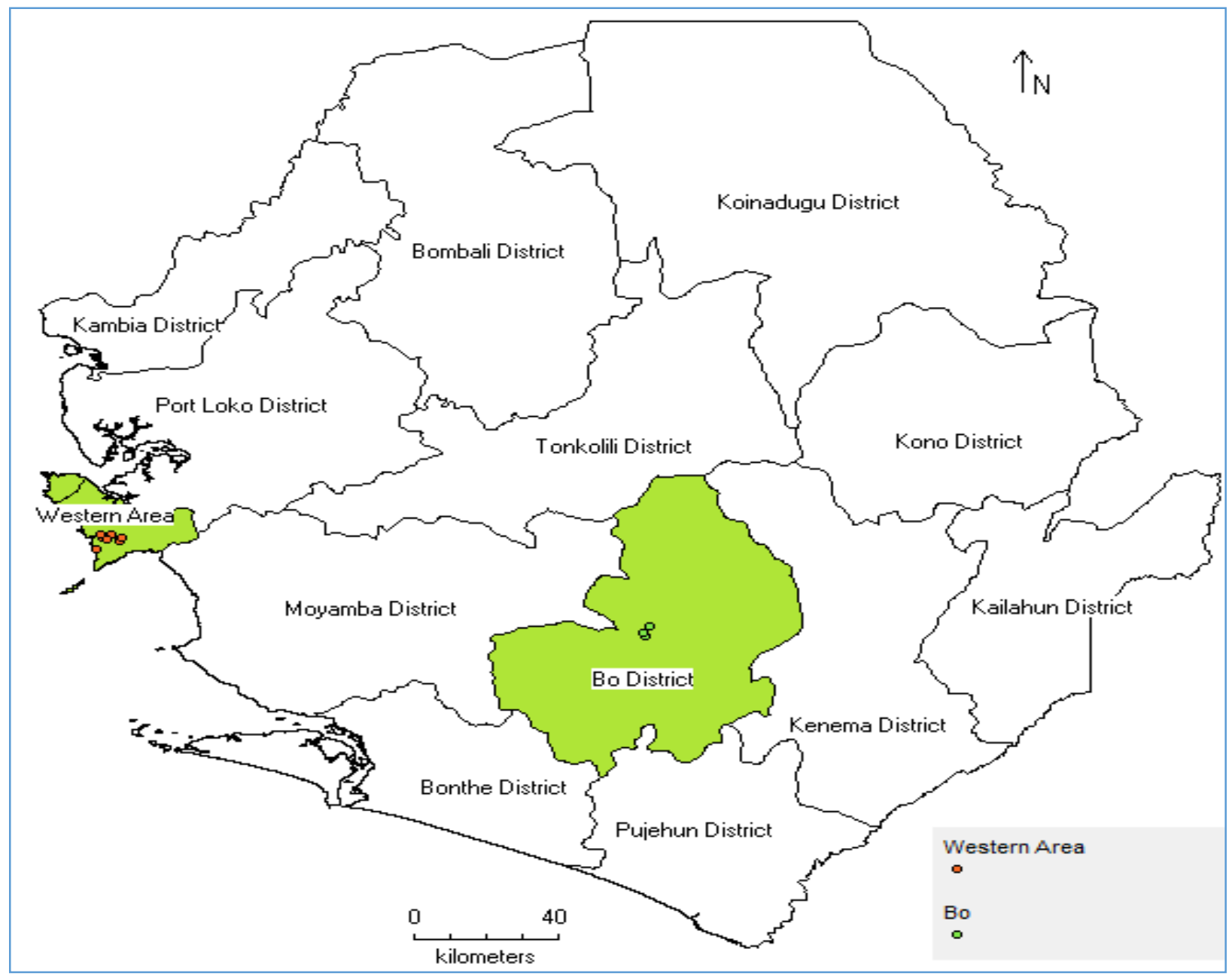

Figure 1. Map of Sierra Leone showing study locations.

2016. Soil and plant samples were collected in July 2016. Shoots of sweet potato (Ipomoea batatas (L.) Lam) were also sampled, as this crop was found in all the sites sampled. Furthermore, this crop is mostly grown in urban farms for the leaves, which are consumed extensively in Sierra Leone as a source of vegetable protein. Using a clean stainless steel shovel, the soil samples were carefully dug out from 0 to $15 \mathrm{~cm}$ depth around the plant and the plants were pulled out carefully, ensuring that no part of the root was lost. Plant and soil samples were kept in separate polythene bags and properly labeled. All soil samples were spread on plastic trays and allowed to dry at ambient temperature for 8 days. The dried samples of soils were then ground with a ceramic coated grinder and sieved through a nylon sieve. The final samples were kept in labeled polypropylene containers at ambient temperature before analysis. Compost samples were also collected from selected farms to identify the potential toxicity of these compost materials that are applied to the soils.

In order to eliminate dust, dirt, and possible parasites or their eggs, the plant samples were initially washed in fresh running water and then again washed with deionized water. The cleaned plant samples were air-dried and then placed in an electric oven at $65^{\circ} \mathrm{C}$ for $72 \mathrm{~h}$. The dried plant samples were then homogenized by grinding using a ceramic coated grinder normally used for metal analysis.

\section{Soil characterization}

Soil analyses for site characterization were carried out using methods described jointly by the International Soil Reference and Information Centre (ISRIC) and the FAO (ISRIC/FAO, 2002). Soil colour was visually compared with the Munsell Chart. Soil pH was determined on 1:1 soil:water and 1:1 soil: $\mathrm{KCl}$ extracts. Exchangeable cations $(\mathrm{Na}, \mathrm{K}, \mathrm{Ca}$ and $\mathrm{Mg}$ ) were measured on neutral $1 \mathrm{~N}$ ammonium acetate extracts. Exchangeable $\mathrm{K}$ and $\mathrm{Na}$ were read on a Flame Photometer while exchangeable $\mathrm{Ca}$ and $\mathrm{Mg}$ were read on an Atomic Absorption 
Table 1. Summary of Soil characteristics across all sampled sites.

\begin{tabular}{lccccc}
\hline Parameters & Minimum & Maximum & Mean & Median & $\begin{array}{c}\text { Coefficient of } \\
\text { Variability (\%) }\end{array}$ \\
\hline $\mathrm{pH}(1: 1 \mathrm{H} 2 \mathrm{O})$ & 4.33 & 5.83 & 4.97 & 4.96 & 6.80 \\
$\mathrm{pH}(\mathrm{KCl})$ & 3.82 & 4.89 & 4.16 & 4.15 & 5.07 \\
$\%$ Organic Carbon & 0.60 & 3.00 & 1.79 & 1.60 & 37.35 \\
Total Nitrogen $(\%)$ & 0.07 & 0.16 & 0.12 & 0.12 & 23.45 \\
$\mathrm{P}($ Bray 1$) \mathrm{mg} / \mathrm{kg}$ & 1.16 & 8.35 & 3.06 & 2.54 & 54.46 \\
Exchangeable $\mathrm{K} \mathrm{cmol}(+) / \mathrm{kg}$ & 0.11 & 0.95 & 0.56 & 0.74 & 60.27 \\
Exchangeable Ca cmol $(+) / \mathrm{kg}$ & 1.10 & 2.45 & 1.77 & 1.90 & 23.71 \\
Exchangeable $\mathrm{Mg} \mathrm{cmol}(+) / \mathrm{kg}$ & 0.35 & 1.55 & 1.18 & 1.35 & 32.33 \\
Exchangeable $\mathrm{Na} \mathrm{cmol}(+) / \mathrm{kg}$ & 0.05 & 0.45 & 0.17 & 0.15 & 58.75 \\
Exchangeable Acidity $(\mathrm{H}+\mathrm{Al}) \mathrm{cmol}(+) / \mathrm{kg}$ & 3.40 & 5.49 & 4.77 & 4.79 & 8.29 \\
Effective CEC cmol $(+) / \mathrm{kg}$ & 6.95 & 9.78 & 8.46 & 8.48 & 8.77 \\
\hline
\end{tabular}

Spectrophotometer (AAS 205, Buck Scientific). Exchangeable Acidity $(\mathrm{Al}+\mathrm{H})$ was extracted by $1 \mathrm{M} \mathrm{KCl}$ and titrated with $0.025 \mathrm{M} \mathrm{NaOH}$. Effective Cation Exchange Capacity (CEC) was calculated as the sum of exchangeable cations and exchangeable acidity (Table 1).

\section{Digestion and determination of heavy metals}

For the analysis of heavy metals in soils, $2.0 \mathrm{~g}$ of prepared soil sample was digested with a mixture of 15.0 $\mathrm{ml}$ nitric acid $\left(\mathrm{HNO}_{3}\right), 20.0 \mathrm{ml}$ perchloric acid $\left(\mathrm{HClO}_{4}\right)$ and $15.0 \mathrm{ml}$ hydrofluoric acid (HF) and placed on a hot plate for 3 hours. On cooling, the digest was filtered into a $100.0 \mathrm{ml}$ volumetric flask and made up to the mark with distilled water. Blanks were prepared to check for background contamination by the reagents used (Louhi et al., 2012).

The plant samples were digested using the nitricperchloric acid digestion, following the procedure recommended by the AOAC (1990). One gram of plant sample was placed in a $250 \mathrm{ml}$ digestion tube and $10 \mathrm{ml}$ of concentrated $\mathrm{HNO}_{3}$ was added. The mixture was boiled gently for 30 to $45 \mathrm{~min}$ to oxidize all easily oxidizable matter. After cooling, $5 \mathrm{ml}$ of $70 \% \mathrm{HClO}_{4}$ was added and the mixture was boiled gently until dense white fumes appeared. After cooling, $20 \mathrm{ml}$ of distilled water was added and the mixture was boiled further to release any fumes. The solution was cooled, further filtered through Whatman No. 42 filter paper and then transferred quantitatively to a $25 \mathrm{ml}$ volumetric flask by adding distilled water (Farid et al., 2015).

Analytical grade chemicals were used throughout the analysis. There was no further purification for the preparation of all reagents and calibration standards. Deionized water was used with conductivity $<1 \mathrm{dS} / \mathrm{cm}$. Certified metal stock solutions of $1000 \mathrm{mg} / \mathrm{L}$ were used by successively diluting with deionized water for preparing calibration standards.

\section{Determination of heavy metals}

The heavy metal ( $\mathrm{Zn}, \mathrm{Cu}, \mathrm{Cr}, \mathrm{Ni}, \mathrm{Pb}$ and $\mathrm{Cd}$ ) concentrations were determined by atomic absorption spectrometry using a BUCK SCIENTIFIC Atomic Absorption Spectrophotometer (AAS 205, Buck Scientific, CT, USA) equipped with hollow cathode lamps. The spectral range extends at least from 180 to $900 \mathrm{~nm}$. Quality control was based on the use of standard metal solutions and duplicate analysis (Louhi et al., 2012).

\section{Methods of potential ecological risk assessment}

Hakanson's potential ecological risk method was used to assess the potential ecological risk of the heavy metal (Hakanson, 1980). This method is able to reflect the effects of various contaminants and reveal the comprehensive influence of multiple contaminants in a particular environment. The specific calculating formulas are as follows:

The single Contamination Coefficient, $\mathbf{C}_{\boldsymbol{f}}$, of a particular heavy metal and is given by:

$\mathrm{C}_{f}=\mathrm{C}_{\mathrm{i}} / \mathrm{C}_{\mathrm{b}}$

Where, $\mathrm{C}_{\mathrm{i}}$ is the measured heavy metal content in the soil and $C_{b}$ is a reference value. The reference value used here is the background content of the soil metal without contamination (Table 2).

The Potential Ecological Risk index, $\mathbf{E R}_{\mathbf{i}}$, of a particular heavy metal $i$, is given by:

$E R_{i}=T_{i} \times C_{i}$

Where, $T_{i}$ is the Toxic Response Factor of a particular heavy metal (Table 3 ) and $\mathrm{C}_{i}$ is the Contamination Coefficient of that metal. 
Table 2. Typical and unsafe heavy metal soil levels ( $\mathrm{mg} / \mathrm{kg}$ sample).

\begin{tabular}{lllllll}
\hline Metal & $\mathbf{Z n}$ & $\mathbf{C u}$ & $\mathbf{C r}$ & $\mathbf{N i}$ & $\mathbf{P b}$ & $\mathbf{C d}$ \\
\hline Typical background Levels for Uncontaminated Soil & 125 & 50 & 90 & 50 & 70 & 1.0 \\
Unsafe for Leafy or Root Vegetables & 200 & 200 & 100 & 200 & 500 & 10 \\
\hline
\end{tabular}

Source: Interpreting Soil Heavy Metals. A\&L Eastern Laboratories, Inc. 7621Whitepine Road. Richmond, Virginia 23237-2296. www.al-labs-eastern.com.

Table 3. Toxic response factor for selected heavy metals in soils.

\begin{tabular}{lcccccc}
\hline Elements & $\mathbf{Z n}$ & $\mathbf{C u}$ & $\mathbf{C r}$ & $\mathbf{N i}$ & $\mathbf{P b}$ & $\mathbf{C d}$ \\
\hline Toxic response factor & 1 & 5 & 2 & 2 & 5 & 30 \\
\hline
\end{tabular}

Source: Hakanson, 1980; Mugoša et al., 2016.

Table 4. Categories of sampled sites.

\begin{tabular}{lcccc}
\hline \multirow{2}{*}{ Urban Centre } & \multirow{2}{*}{ Category Title } & Number of & \multicolumn{2}{c}{ Central GPS Coordinate } \\
\cline { 4 - 5 } & Sites Sampled & Longitude (-W) & Latitude (oN) \\
\hline Bo & Bo1 & 4 & $7^{\circ} 57.830$ & $11^{\circ} 43.370$ \\
Bo & Bo2 & 4 & $7^{\circ} 57.427$ & $11^{\circ} 47.650$ \\
Bo & Bo3 & 4 & $7^{\circ} 57.263$ & $11^{\circ} 44.789$ \\
Bo & Bo4 & 4 & $7^{\circ} 55.267$ & $11^{\circ} 43.190$ \\
Western Rural & WR1 & 6 & $8^{\circ} 19.136$ & $13^{\circ} 03.578$ \\
Western Rural & WR2 & 6 & $8^{\circ} 25.886$ & $13^{\circ} 12.493$ \\
Western Rural & WR3 & 5 & $8^{\circ} 24.319$ & $13^{\circ} 15.753$ \\
Western Urban & WU1 & 8 & $8^{\circ} 27.601$ & $13^{\circ} 12.979$ \\
Western Urban & WU2 & 8 & $8^{\circ} 28.424$ & $13^{\circ} 11.612$ \\
Western Urban & WU3 & 8 & $8^{\circ} 26.903$ & $13^{\circ} 09.616$ \\
Western Urban & WU4 & 7 & $8^{\circ} 27.296$ & $3^{\circ} 10.035$ \\
Western Urban & WU5 & 8 & $8^{\circ} 29.138$ & $13^{\circ} 14.798$ \\
\hline
\end{tabular}

The toxic-response factor for the given element mainly reflects the heavy metal toxicity level and the degree of environment sensitivity to heavy metal pollution. The toxic response factor represents the potential hazard of heavy metal contamination by indicating the toxicity of particular heavy metals and the environmental sensitivity to contamination.

Data were analyzed using descriptive statistics, correlation and regression analysis using Microsoft Excelo.

\section{RESULTS AND DISCUSSION}

The 72 urban and peri-urban sites identified were categorized into 12 groups, based on proximity of Global Positioning System (GPS) Coordinates (Table 4). While variations existed, it appears from the data that the levels of heavy metals in all sites were mostly below the reference values. In general, the heavy metal concentrations tend to increase as we move from Bo in the south of the country to the major urban center,
Freetown (Table 5).

Mean $\mathrm{Zn}$ content of the soils across all sites ranged between 24.19 and $106.79 \mathrm{mg} / \mathrm{kg}$ as compared to a reference value of $125 \mathrm{mg} / \mathrm{kg}$ while the mean Cu content of the soils across all sites ranged between 15.53 and $77.14 \mathrm{mg} / \mathrm{kg}$ as compared to a reference value of 50 $\mathrm{mg} / \mathrm{kg}$ (Table 5). While the lowest concentration of heavy metal was observed with the $\mathrm{Cd}$, there were more sites showing higher $\mathrm{Cd}$ content than the reference value as compared to the other metals.

Mean values for $\mathrm{Cr}, \mathrm{Ni}$ and $\mathrm{Pb}$ ranged between 22.85 and $59.66 \mathrm{mg} / \mathrm{kg}, 10.42$ and $46.00 \mathrm{mg} / \mathrm{kg}$, and 14.79 and $74.34 \mathrm{mg} / \mathrm{kg}$ respectively. The highest mean concentration of $\mathrm{Zn}, \mathrm{Cu}, \mathrm{Cr}, \mathrm{Ni}$ and $\mathrm{Pb}$ were observed in WU4 (Table 5). This does not come as a surprise because WU4 is a densely populated region of Freetown in the Western Urban district with massive and uncontrollable deposition of domestic and industrial waste. In terms of mean values of heavy metals in the various locations studied, the trend observed is $\mathrm{Zn}>\mathrm{Pb}>\mathrm{Cu}>\mathrm{Cr}>\mathrm{Ni}>\mathrm{Cd}$. 
Table 5. Means of heavy metal levels in soil samples from different locations $(\mathrm{mg} / \mathrm{kg})$.

\begin{tabular}{lcccccc}
\hline Location & $\mathbf{Z n} \pm \mathbf{s d}$ & $\mathbf{C u} \pm \mathbf{s d}$ & $\mathbf{C r} \pm \mathbf{s d}$ & $\mathbf{N i} \pm \mathbf{s d}$ & $\mathbf{P b} \pm \mathbf{s d}$ & $\mathbf{C d} \pm \mathbf{s d}$ \\
\hline Bo1 & $40.63 \pm 3.66$ & $15.53 \pm 1.40$ & $22.85 \pm 2.06$ & $10.42 \pm 0.94$ & $21.29 \pm 1.92$ & $0.85 \pm 0.08$ \\
Bo2 & $30.13 \pm 3.62$ & $21.71 \pm 2.61$ & $23.02 \pm 2.07$ & $21.5 \pm 12.15$ & $14.79 \pm 1.77$ & $0.59 \pm 0.06$ \\
Bo3 & $24.19 \pm 1.94$ & $19.24 \pm 1.54$ & $24.49 \pm 2.94$ & $21.49 \pm 1.72$ & $17.54 \pm 1.40$ & $0.77 \pm 0.06$ \\
Bo4 & $25.94 \pm 3.37$ & $17.22 \pm 2.24$ & $36.93 \pm 5.54$ & $15.17 \pm 1.67$ & $21.62 \pm 2.81$ & $0.91 \pm 0.10$ \\
WR1 & $63.25 \pm 9.49$ & $32.33 \pm 4.85$ & $44.93 \pm 4.49$ & $28.70 \pm 2.58$ & $26.20 \pm 3.93$ & $1.17 \pm 0.11$ \\
WR2 & $50.99 \pm 4.08$ & $20.77 \pm 1.66$ & $38.04 \pm 3.04$ & $25.40 \pm 3.30$ & $32.52 \pm 2.60$ & $1.09 \pm 0.14$ \\
WR3 & $60.90 \pm 9.74$ & $30.30 \pm 4.85$ & $32.79 \pm 4.59$ & $29.09 \pm 3.20$ & $25.61 \pm 4.10$ & $1.21 \pm 0.13$ \\
WU1 & $92.32 \pm 12.93$ & $41.10 \pm 5.75$ & $40.68 \pm 7.32$ & $39.47 \pm 4.74$ & $44.47 \pm 6.23$ & $1.05 \pm 0.13$ \\
WU2 & $64.18 \pm 10.91$ & $30.25 \pm 5.14$ & $40.21 \pm 6.43$ & $37.65 \pm 5.65$ & $36.60 \pm 6.22$ & $0.96 \pm 0.14$ \\
WU3 & $78.13 \pm 7.81$ & $40.30 \pm 4.03$ & $42.70 \pm 4.27$ & $35.42 \pm 5.67$ & $50.74 \pm 5.07$ & $1.09 \pm 0.17$ \\
WU4 & $106.79 \pm 14.95$ & $77.14 \pm 10.80$ & $59.66 \pm 9.55$ & $46.00 \pm 6.44$ & $74.34 \pm 10.41$ & $0.96 \pm 0.13$ \\
WU5 & $100.81 \pm 16.13$ & $53.99 \pm 8.64$ & $42.00 \pm 7.56$ & $45.30 \pm 8.15$ & $69.84 \pm 11.17$ & $1.21 \pm 0.22$ \\
Reference & 125.00 & 50.00 & 90.00 & 50.00 & 70.00 & 1.00 \\
\hline \multicolumn{7}{c}{} \\
\end{tabular}

Table 6. Variability in heavy metal content of soil and plant samples across all sites.

\begin{tabular}{lrrrrrr}
\hline Parameters & Zn & Cu & Cr & Ni & Pb & Cd \\
\hline Soil levels (mg/kg) & & & & & & \\
Min & & & & & & \\
Max & 8.50 & 10.13 & 0.96 & 10.05 & 10.00 & 0.25 \\
Mean & 180.00 & 118.13 & 73.00 & 67.70 & 136.27 & 1.65 \\
SD & 65.04 & 35.31 & 38.67 & 31.30 & 38.46 & 1.01 \\
Reference & 44.54 & 25.49 & 15.25 & 11.81 & 27.27 & 0.28 \\
& 125.00 & 50.00 & 90.00 & 50.00 & 70.00 & 1.00 \\
Plant levels (mg/kg) & & & & & & \\
Min & & & & & & \\
Max & 0.34 & 0.74 & 0.59 & 0.04 & 0.21 & 0.01 \\
Mean & 4.99 & 5.59 & 1.70 & 0.20 & 1.30 & 0.05 \\
SD & 2.04 & 2.01 & 1.00 & 0.12 & 0.55 & 0.04 \\
Reference & 1.51 & 1.36 & 0.30 & 0.05 & 0.33 & 0.01 \\
& 60.00 & 10.00 & 1.30 & 10.00 & 2.00 & 1.00 \\
\hline
\end{tabular}

Table 7. FAO/WHO guidelines for metals in foods and vegetables (mg/kg dry weight).

\begin{tabular}{lcccccc}
\hline Metal & $\mathbf{C d}$ & $\mathbf{C u}$ & $\mathbf{P b}$ & $\mathbf{Z n}$ & $\mathbf{C r}$ & $\mathbf{N i}$ \\
\hline WHO/FAO Limits & 1 & 10 & 2 & 60 & 1.3 & 10 \\
Normal Range in Plants & $<2.4$ & 2.5 & $0.5-30$ & $20-100$ & - & $0.002-50$ \\
\hline
\end{tabular}

Source: Opaluwa et al., 2012; Nazir et al., 2015.

However, when individual sampled points were considered, the ranges observed in heavy metal concentration were much greater than those observed from the clustered locations. For instance, $\mathrm{Zn}$ ranged from a minimum of $8.50 \mathrm{mg} / \mathrm{kg}$ to a maximum of 180 $\mathrm{mg} / \mathrm{kg}$ while $\mathrm{Pb}$ ranged from a minimum of $10 \mathrm{mg} / \mathrm{kg}$ to a maximum of $136 \mathrm{mg} / \mathrm{kg}$ (Table 6). The overall means of heavy metals across all sites is in the order $\mathrm{Zn}>\mathrm{Pb}>\mathrm{Cu}>\mathrm{Cr}>\mathrm{Ni}>\mathrm{Cd}$. This sequence is different from that observed in Nigeria by Opaluwa et al. (2012) in which the occurrence was $\mathrm{Cu}>\mathrm{Cd}>\mathrm{As}>\mathrm{Fe}>\mathrm{Co}>\mathrm{Pd}$ $>\mathrm{Zn}>\mathrm{Ni}$ in soil samples from one site and $\mathrm{Cd}>\mathrm{Cu}>\mathrm{Fe}$ $>\mathrm{Co}>\mathrm{As}>\mathrm{Pb}>\mathrm{Ni}>\mathrm{Zn}$ in soil sample from another site. With the exception of $\mathrm{Cr}$, the maximum values for all other heavy metals studied were higher than the reference value (Table 6 ), an indication of potential heavy metal toxicity in some of these sites.

Although the plants (Table 6) took up some heavy metals, the quantities in most cases appear to be less than the reference values given by the WHO/FAO guidelines (Table 7). As was observed with the heavy metal content in soils, the trend in heavy metal uptake in plants tends to increase from Bo to Freetown, with $\mathrm{Zn}$ and $\mathrm{Cu}$ appearing to have the greatest uptake levels especially in the western urban and western rural locations (Figure 2). 


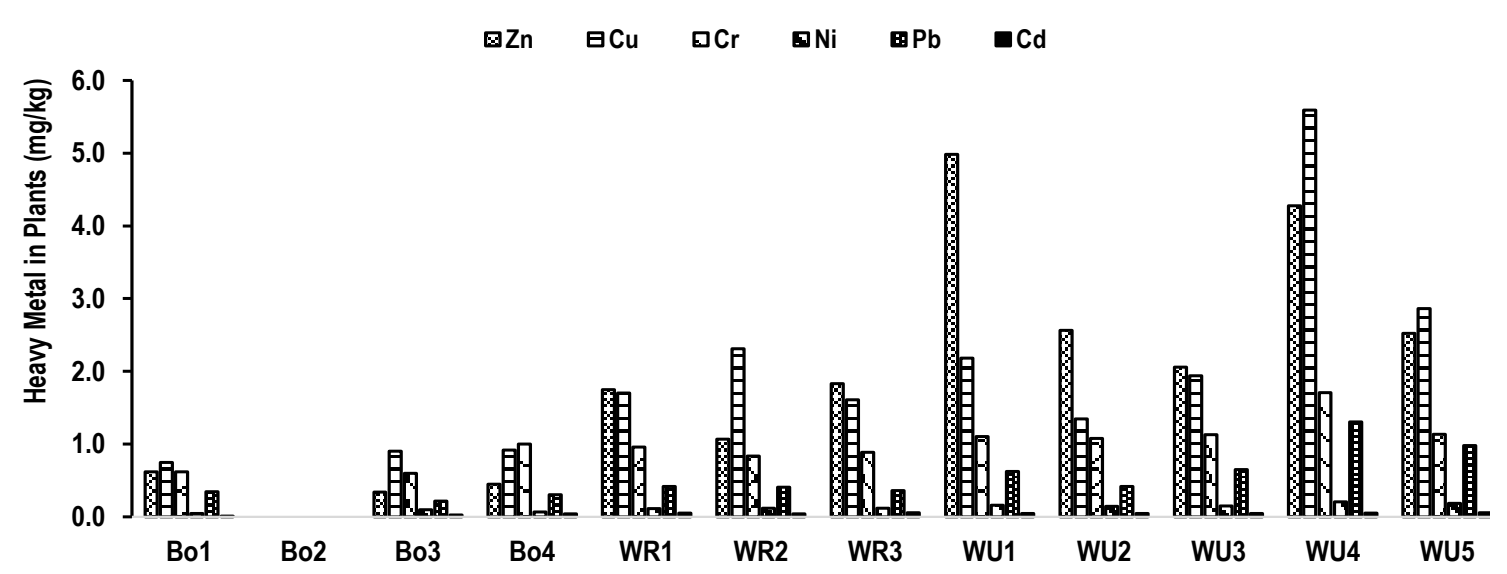

Figure 2. Heavy metal content in plant samples from all locations.

Table 8. Maximum Allowable Limits for Heavy Metals in Soils for Different Countries $(\mathrm{mg} / \mathrm{kg})$.

\begin{tabular}{lcccccc}
\hline Element & Austria & Canada & Poland & Japan & UK & Germany \\
\hline $\mathrm{Zn}$ & 300 & 400 & 300 & 250 & 300 & 300 \\
$\mathrm{Cu}$ & 100 & 100 & 100 & 125 & 100 & 50 \\
$\mathrm{Cr}$ & 100 & 75 & 100 & - & 50 & 200 \\
$\mathrm{Ni}$ & 100 & 100 & 100 & 100 & 50 & 100 \\
$\mathrm{~Pb}$ & 100 & 200 & 100 & 400 & 100 & 500 \\
$\mathrm{Cd}$ & 5 & 8 & 3 & - & 3 & 2 \\
\hline
\end{tabular}

Source: Lacatusu, 2000; Fagbote and Olanipekun, 2010.

Sierra Leone has not established limits for heavy metal concentration in soils or plants. However, it can be seen that values obtained for our samples fall below those values established in other countries (Table 8). Across all sites and for all plant samples, the heavy metal contents were below the standards given by the $\mathrm{FAO} / \mathrm{WHO}$ as shown in Table 6.

The soil contamination index showed some mild risk of heavy metal toxicity in selected locations (Table 10). Soil samples collected from Western Urban 4 (WU4) are particularly at a mild risk of toxicity from copper and lead. Western Urban 5 (WU5) shows light risk of pollution by copper, lead and cadmium (Table 10). This area is a major dump site in Freetown with lots of urban gardening taking place around this site. Despite the very low quantities of $\mathrm{Cd}$ observed in all sites, a risk of contamination by $\mathrm{Cd}$ occurs in more sites than any of the other metals examined. This is mostly due to the high toxicity factor of $\mathrm{Cd}$ (Table 3 ). As stated earlier in this report, the toxic-response factor for the given element mainly reflects the potential hazard of heavy metal contamination by indicating the toxicity of particular heavy metals and the environmental sensitivity to contamination.

The corresponding degrees of contamination and the grading standards for the levels of potential ecological risk in $\mathrm{C}_{f}$ and $\mathrm{ER}$ are shown in Table 11. As can be seen from the degree of contamination for particular heavy metals and the corresponding grading standards for potential ecological risk (Table 11), and the variability in soil contamination factor and ecological risk factor across all sites (Table 9), mean values for contamination factor of all heavy metals, except $\mathrm{Cd}$, are below 1.0. This means that no major risk of contamination exist at this moment for these metals, except for $\mathrm{Cd}$ which shows a mean contamination factor greater than 1.0 (Table 9).

According to the calculated accumulating coefficients (Tables 10 and 12), cadmium appears to be the main heavy metal posing serious toxicity risks in the areas studied. The potential ecological risk tends to increase towards the major urban centers. In a nutshell, the heavy metals under investigation in soils and plants reflected a low ecological risk (Table 12) with the exception of cadmium, which posed a moderate ecological risk (Table 10) in the western area. In the densely populated areas of the western area where intense dumping of garbage occurs, some potential contamination risk for copper and lead was detected (Table 10).

To analyze the relationships among metal concentrations, a Pearson's correlation analysis was applied 
Table 9. Variability in soil contamination factor and ecological risk factor across all sites.

\begin{tabular}{|c|c|c|c|c|c|c|}
\hline Parameters & $\mathrm{Zn}$ & $\mathrm{Cu}$ & $\mathrm{Cr}$ & $\mathbf{N i}$ & $\mathrm{Pb}$ & $\mathrm{Cd}$ \\
\hline \multicolumn{7}{|c|}{ Soil Contamination factor (Cf) } \\
\hline Min & 0.19 & 0.20 & 0.25 & 0.21 & 0.14 & 0.59 \\
\hline Max & 0.85 & 1.54 & 0.66 & 0.92 & 1.95 & 1.21 \\
\hline Mean & 0.52 & 0.71 & 0.43 & 0.63 & 0.55 & 1.01 \\
\hline SD & 0.26 & 0.41 & 0.17 & 0.14 & 0.29 & 0.18 \\
\hline \multicolumn{7}{|c|}{ Ecological Risk Factor factor (Er) } \\
\hline Min & 0.19 & 1.55 & 0.51 & 1.04 & 1.06 & 17.63 \\
\hline Max & 0.85 & 7.71 & 1.33 & 4.60 & 5.31 & 36.30 \\
\hline Mean & 0.52 & 3.53 & 0.86 & 3.13 & 2.75 & 30.34 \\
\hline SD & 0.26 & 1.55 & 0.24 & 1.08 & 1.95 & 8.52 \\
\hline
\end{tabular}

Table 10. Soil Contamination Index across all locations.

\begin{tabular}{lccccccc}
\hline \multirow{2}{*}{ Locations } & \multicolumn{9}{c}{ Soil Contamination factor (Cf) } & \multirow{2}{*}{ ¿Cf } \\
\cline { 2 - 6 } & $\mathbf{Z n}$ & $\mathbf{C u}$ & $\mathbf{C r}$ & $\mathbf{N i}$ & $\mathbf{P b}$ & $\mathbf{C d}$ & \\
\hline B01 & 0.33 & 0.31 & 0.25 & 0.21 & 0.30 & 0.85 & 2.25 \\
B02 & 0.24 & 0.43 & 0.26 & 0.43 & 0.21 & 0.59 & 2.16 \\
Bo3 & 0.19 & 0.38 & 0.27 & 0.43 & 0.25 & 0.77 & 2.30 \\
B04 & 0.21 & 0.34 & 0.41 & 0.30 & 0.31 & 0.91 & 2.49 \\
WR1 & 0.51 & 0.65 & 0.50 & 0.57 & 0.37 & 1.17 & 3.77 \\
WR2 & 0.41 & 0.42 & 0.42 & 0.51 & 0.46 & 1.09 & 3.31 \\
WR3 & 0.49 & 0.61 & 0.36 & 0.58 & 0.37 & 1.21 & 3.61 \\
WU1 & 0.74 & 0.82 & 0.45 & 0.79 & 0.64 & 1.05 & 4.49 \\
WU2 & 0.51 & 0.61 & 0.45 & 0.75 & 0.52 & 0.96 & 3.80 \\
WU3 & 0.63 & 0.81 & 0.47 & 0.71 & 0.72 & 1.09 & 4.43 \\
WU4 & 0.85 & 1.54 & 0.66 & 0.92 & 1.06 & 0.96 & 6.00 \\
WU5 & 0.81 & 1.08 & 0.47 & 0.91 & 1.00 & 1.21 & 5.47 \\
\hline
\end{tabular}

\begin{tabular}{|l|l}
\hline No Risk & Light Risk \\
\hline
\end{tabular}

Table 11. Degree of contamination for particular heavy metals and the corresponding grading standards for potential ecological risk.

\begin{tabular}{llllll}
\hline Risk Index & \multicolumn{5}{c}{ Ranges and Level of Toxicity/Pollution Risk } \\
\hline $\mathbf{C}_{\mathbf{f}}$ & $<1$; None & $1-2$; light & $2-3$; moderate & $>3$; heavy \\
ER & $<40 ;$ low & $40-80$ : moderate & $80-100 ;$ strong & $100-320$; very strong & $>320$; extremely strong \\
\hline
\end{tabular}

Source: Hakanson., 1980; Mugoša et al., 2016.

(Table 13). Based on data shown in Table 13, Zn, Cu, Cr, $\mathrm{Ni}$ and $\mathrm{Pb}$ were all strongly correlated with each other, while $\mathrm{Cd}$ is only weakly correlated with $\mathrm{Zn}$. It was interesting to note that $\mathrm{Cd}$ did not have any significant correlation with any of $\mathrm{Cu}, \mathrm{Cr}, \mathrm{Ni}$, or $\mathrm{Pb}$. Reasons for this observation are not immediately clear, but very likely due to different origins of $\mathrm{Cd}$ compared to the other metals studied.
It was also interesting to note that for all locations, the heavy metal accumulation in plants was well below the limit set by the FAO/WHO. This observation was particularly relevant for $\mathrm{Cd}$ which appears to be higher in most of the western area than the reference values used. Despite this potential risk, Cd values in all plant samples were way below the FAO/WHO limits. This means that Cd uptake by plants was low. 
Table 12. Ecological Risk Factor (Er) of Soils.

\begin{tabular}{|c|c|c|c|c|c|c|c|}
\hline \multirow{2}{*}{ Locations } & \multicolumn{6}{|c|}{ Ecological Risk Factor (Er) of Soils } & \multirow{2}{*}{$\Sigma \mathrm{ER}$} \\
\hline & Zn & $\mathrm{Cu}$ & $\mathrm{Cr}$ & $\mathbf{N i}$ & $\mathbf{P b}$ & Cd & \\
\hline Bo1 & 0.33 & 1.55 & 0.51 & 1.04 & 1.52 & 25.38 & 30.33 \\
\hline Bo2 & 0.24 & 2.17 & 0.51 & 2.15 & 1.06 & 17.63 & 23.76 \\
\hline Bo3 & 0.19 & 1.92 & 0.54 & 2.15 & 1.25 & 23.14 & 29.20 \\
\hline Bo4 & 0.21 & 1.72 & 0.82 & 1.52 & 1.54 & 27.43 & 33.24 \\
\hline WR1 & 0.51 & 3.23 & 1.00 & 2.87 & 1.87 & 35.06 & 44.54 \\
\hline WR2 & 0.41 & 2.08 & 0.85 & 2.54 & 2.32 & 32.80 & 40.99 \\
\hline WR3 & 0.49 & 3.03 & 0.73 & 2.91 & 1.83 & 36.21 & 45.19 \\
\hline WU1 & 0.74 & 4.11 & 0.90 & 3.95 & 3.18 & 31.63 & 44.51 \\
\hline WU2 & 0.51 & 3.03 & 0.89 & 3.76 & 2.61 & 28.66 & 39.47 \\
\hline WU3 & 0.63 & 4.03 & 0.95 & 3.54 & 3.62 & 32.70 & 45.47 \\
\hline WU4 & 0.85 & 7.71 & 1.33 & 4.60 & 5.31 & 28.71 & 48.52 \\
\hline WU5 & 0.81 & 5.40 & 0.93 & 4.53 & 4.99 & 36.30 & 52.95 \\
\hline
\end{tabular}

\begin{tabular}{|l|l}
\hline No Risk & Light Risk
\end{tabular}

Table 13. Correlation matrix between heavy metals in soil.

\begin{tabular}{lccccc}
\hline Parameters & $\mathrm{Zn}$ & $\mathrm{Cu}$ & $\mathrm{Cr}$ & $\mathrm{Ni}$ & $\mathrm{Pb}$ \\
\hline $\mathrm{Zn}$ & - & - & - & - & - \\
$\mathrm{Cu}$ & $0.6495^{\star *}$ & - & - & - & - \\
$\mathrm{Cr}$ & $0.4686^{\star *}$ & $0.6471^{* *}$ & - & - & - \\
$\mathrm{Ni}$ & $0.5392^{* *}$ & $0.6892^{* *}$ & $0.4891^{\star *}$ & - & - \\
$\mathrm{Pb}$ & $0.5596^{\star *}$ & $0.7922^{* *}$ & $0.5656^{* *}$ & $0.6956^{* *}$ & - \\
$\mathrm{Cd}$ & $0.4134^{*}$ & $0.2193 \mathrm{~ns}$ & $0.2615 \mathrm{~ns}$ & $0.2711 \mathrm{~ns}$ & $0.1792 \mathrm{~ns}$ \\
\hline
\end{tabular}

*Significant at $\mathrm{P}<0.05$; ** significant at $\mathrm{P}<0.01$; ns not significant.

Absorption of heavy metals by roots is known to be controlled by the concentration of other elements and some interactions have often been reported. These interactions may be positive or negative; the uptake of a given element being improved or depressed by others present at high concentrations in the soil. Macronutrients interfere antagonistically with uptake of trace elements. For example, calcium controls the absorption of $\mathrm{Cd}$, because of competition for available absorption sites at the root surface. $\mathrm{Cd}$ and $\mathrm{Zn}$ interact in the soil-plant system, causing the well-known $\mathrm{Cd} / \mathrm{Zn}$ antagonism (Smilde et al., 1992). Zn depresses Cd uptake (Cataldo et al., 1983). The relatively high levels of on $\mathrm{Zn}$ measured in this study compared to the other metals could have inhibited the uptake of $\mathrm{Cd}$.

The availability to plants of heavy metals from the soil is also controlled by plant micronutrient requirements and their ability to take up or exclude toxic elements. Some plants are well adapted for survival in stressful environmental conditions. They can hold in their tissues amounts higher than $1 \%$ of the metal and up to $25 \%$ on a dry matter basis. When grown in the same soil, accumulation of $\mathrm{Cd}$ by different plant species decreases in the order: leafy vegetables > root vegetables > grain crops (Morel, 1997). Therefore, screening of cultivars that exclude toxic elements should be a priority to protect food quality.

Given that many urban gardens are located on or close to garbage dump site (Figure 3), this study also examined the heavy metal content of garbage found around urban gardens. This was done to determine the potential contribution of garbage applied to urban farms in contributing to heavy metal toxicity. Contamination factor was calculated using soil reference values due partly to the absence of reference values for garbage, the heterogeneity of garbage material, and the fact that the garbage is being applied to the soil. Risk posed by urban garbage in heavy metal toxicity ranged from none to heavy risk (Table 14).

With the exception of samples collected from Bo1 locations, all other garbage samples collected from other locations show varying degrees of toxicity. Heavy risk of $\mathrm{Pb}$ contamination was observed in samples from WU4 and WU5 (Table 14). All other heavy metals show light to moderate risk of soil contamination. This observation, however does not relate directly with observations made on soil samples (Table 10) where the greatest contamination risk was from the cadmium. Possibly the cadmium and other heavy metals in soils are from different origins as was seen with the poor correlation between cadmium and the other heavy metals. 


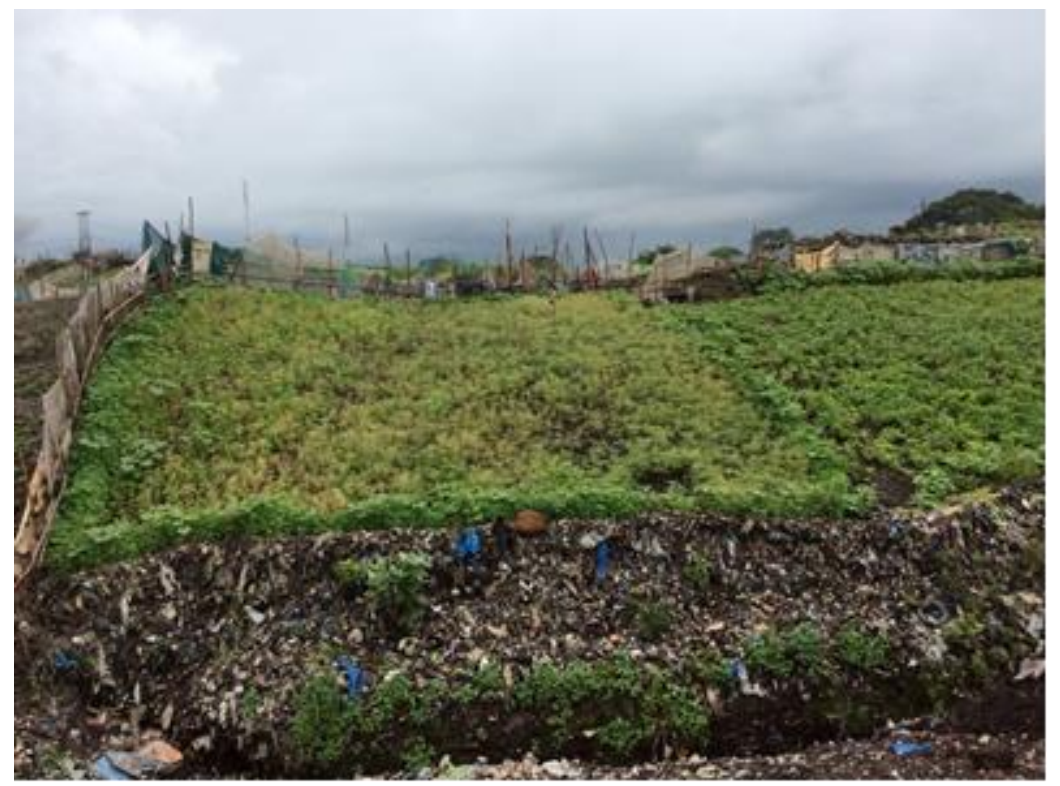

Figure 3. A common urban garden in Freetown showing vegetables (sweet potato) growing on garbage dump.

Table 14. Contamination Factor (Cf) of Garbage across all locations.

\begin{tabular}{|c|c|c|c|c|c|c|}
\hline \multirow[b]{2}{*}{ Locations } & \multicolumn{6}{|c|}{ Garbage Contamination factor (Cf) } \\
\hline & $\mathrm{Zn}$ & $\mathrm{Cu}$ & $\mathrm{Cr}$ & $\mathrm{Ni}$ & $\mathrm{Pb}$ & Cd \\
\hline Bo1 & 0.25 & 0.89 & 0.54 & 0.45 & 0.98 & 0.68 \\
\hline Bo2 & \multicolumn{6}{|c|}{ No Sample Collected } \\
\hline Bo3 & 0.41 & 1.06 & 0.56 & 1.03 & 0.63 & 0.81 \\
\hline Bo4 & 0.76 & 1.44 & 0.85 & 0.75 & 1.20 & 1.35 \\
\hline WR1 & 1.56 & 1.56 & 0.92 & 1.13 & 1.89 & 1.43 \\
\hline WR2 & \multicolumn{6}{|c|}{ No Sample Collected } \\
\hline WR3 & 1.44 & 2.02 & 0.63 & 1.39 & 1.38 & 1.46 \\
\hline WU1 & 1.50 & 1.95 & 0.82 & 1.66 & 1.98 & 1.28 \\
\hline WU2 & 1.50 & 1.89 & 1.21 & 1.65 & 1.92 & 1.43 \\
\hline WU3 & \multicolumn{6}{|c|}{ No Sample Collected } \\
\hline WU4 & 3.12 & 6.68 & 1.54 & 2.36 & 4.69 & 1.58 \\
\hline WU5 & 2.22 & 2.48 & 1.02 & 2.08 & 3.18 & 1.84 \\
\hline
\end{tabular}

\section{Conclusions and recommendations}

Values obtained were mostly below the reference values for both soil and plant samples. Some mild risk of toxicity by $\mathrm{Cd}$ was observed in densely populated areas of Freetown, but this was not reflected in the plant uptake of $\mathrm{Cd}$. For future outlook, the following recommendations are necessary.

1. Collaborate with the Environmental Protection Agency for database of Heavy Metals.
2. Development of Threshold Values and periodic monitoring for trends.

3. Further research and possible ways of site remediation should be considered where contamination has been observed.

4. Calculation of pollution indices should be recognized as a useful tool to reduce pollutant emission and minimize the hazard risks to human health.

5. A legal framework for environmental management and urban planning that includes the management of household waste should be advocated. 
6. Promote environmental education to increase the level of public participation and to develop appropriate mitigation technologies.

7. Create micro-enterprises for recycling operations as a way of achieving financial sustainability.

\section{ACKNOWLEDGEMENT}

The authors are most grateful to West and Central African Council for Agricultural Research and Development (CORAF/WECARD) which funded this work under the project titled: "Negative Externalities of Intensification of land cultivated in peri-urban areas: methods and assessment tools and alternative practices".

\section{CONFLICT OF INTEREST}

The authors declare that they have no conflict of interest.

\section{REFERENCES}

Akinola, M. O., Njoku, K. L., \& Ekeifo, B. E. (2008). Determination of lead, cadmium and chromium in the tissue of an economically important plant grown around a textile industry at Ibeshe, Ikorodu area of Lagos State, Nigeria. Advances in Environmental Biology, 2(1), 25-30.

Amara Denis, M. K., Kamara A., \& Momoh, E. J. J. (2013). Soil Fertility Status of Three Chiefdoms in Pujehun District of Southern Sierra Leone. Research Journal of Agricultural Science, 4(4), 461-464.

Ampofo, E. A., \& Awortwe, D. (2017). Heavy Metal (Cu, Fe and $\mathrm{Zn)}$ Pollution in Soils: Pig Waste Contribution in the Central Region of Ghana. Advances in Applied Science Research, 8(2), 1-10.

AOAC (1990). AOAC official methods of analysis. 15th ed. Association of Official Analytical Chemists, Arlington, Virginia, Pp. 84-85.

Cataldo, D. A., Garland, T. R., \& Wildung, R. E. (1983). Cadmium uptake kinetics in intact soybean plants. Plant Physiology, 73, 844.

CFF (2008). Cities for the Future. Freetown Multi-stakeholder Team 2008. Urban and Peri-urban Agriculture in Freetown: a five year rolling City Strategic Agenda (2008-2013), RUAF. www.ruaf.org

Chatterjee, J., \& Chatterjee, F. (2000). Phytotoxicity of chromium, cobalt and copper in cauliflower. Environmental Pollution, 109, 69-74.

Chibuike, G. U., \& Obiora, S. C. (2014). Heavy Metal Polluted Soils: Effect on Plants and Bioremediation Methods. Applied and Environmental Soil Science, 2014, Article ID 752708, $12 \mathrm{p}$.

Chiroma, T. M, Ebewele, R. O., \& Hymore, F. K. (2014). Comparative Assessement of Heavy Metal Levels In Soil, Vegetables And Urban Grey Waste Water Used For Irrigation In Yola And Kano. International Refereed Journal of Engineering and Science, 3(2), 1-9.

Cofie, O., Drechsel, P., \& Veenhuizen, R. (2003). Contribution of Urban and Periurban Agriculture to Food Security in SubSaharan Africa. RUAF Foundation. Available at http://www.ruaf.org/node/1130
Crusberg, T. C., Mark, S., \& Dilorio, A. (2004). Biomineralization of Heavy Metals. In: Arora, K., Bridge, P., \& Bhatnagar, D. (ed.), Fungal Biotechnology in Agricultural, Food, Environmental Applications. CRC Press. Pp. 674-691.

Fagbote, E. O., \& Olanipekun, E. O. (2010). Evaluation of the Status of Heavy Metal Pollution of Soil and Plant (Chromolaenaodorata) of Agbabu Bitumen Deposit Area, Nigeria. American-Eurasian Journal of Scientific Research, 5(4), 241-248.

FAO (2008a). Urbanization and food security in Sub Saharan Africa. Information paper for the FAO 25th African Regional Conference. Available at: ftp://ftp.fao.org/docrep/fao/meeting/012/k1915e.pdf

FAO (2008b). Urban Agriculture for Sustainable Poverty Alleviation and Food Security. Available at: http://www.fao.org/fileadmin/templates/FCIT/PDF/UPA_WBpaper-Final_October_2008.pdf.

Farid, G., Saifulah, G., Sarwar, N., Ahmad, A., Ghafoor, A., \& Rehman, M. (2015). Heavy Metals (Cd, Ni and $\mathrm{Pb}$ ) Contamination of Soils, Plants and Waters in Madina Town of Faisalabad Metropolitan and Preparation of GIS- Based Maps. Advances in Crop Science and Technology, 1-7.

Ghosh, M., \& Singh, S. P. (2005). A review of phytoremediation of heavy metals and utilization of it's by products. Applied Ecology and Environmental Research, 3(1), 1-18.

Hakanson, L. (1980). An Ecological risk index for aquatic pollution control: a sedimentological approach, Water Research, 14, 975-1001

Isa, K., \& Jimoh, W. L. O., (2013). Determination of heavy metals in soils from dump site of tanneries and farmlands in Challawa Industrial Estate, Kano, Nigeria. Bayero Journal of Pure and Applied Sciences, 6(2), 57-64.

ILO (2015). Sierra Leone 2014 Labour Force Survey Report. International Labour Organization (ILO), September 22, 2015

Jiang, X., Lu, W. X., Zhao, H. Q., Yang, Q. C., \& Yang, Z. P. (2014). Heavy-Metal Pollution around Coal Gangue Dump. Natural Hazards and Earth System Science, 14, 1599-1610.

ISRIC/FAO (2002). Procedures for Soil Analysis. Technical Paper 9, $6^{\text {th }}$ Edition.

Kanu, S., Tengbe, P., Winnebah, T. R. A., \& Konneh, P. (2009). Promoting Urban Agriculture in Post-conflict Greater Freetown Area, Sierra Leone. Urban Agriculture Magazine, 21, 19-21.

Lacatusu, R. (2000). Appraising levels of Soil contamination and pollution with heavy metals. European Soil Bureau, 4, 93402.

Louhi, A. Hammadi, A., \& Achouri, M. (2012). Determination of Some Heavy Metal Pollutants in Sediments of the Seybouse River in Annaba, Algeria. Air, Soil and Water Research, 5, 91-101.

McLaughlin, M. J., Hamon, R. E., McLaren, R. G., Speir, T. W., \& Rogers, S. L. (2000). Review: a bioavailability-based rationale for controlling metal and metalloid contamination of agricultural land in Australia and New Zealand. Australian Journal of Soil Research, 38(6), 1037-1086.

Mecray, E., King J., Appleby, P., \& Hunt, S. (2001). Historical trace metal accumulation in the sediments of an urbanized region of the lake Champlain watershed, Burlington, Vermont. Water, Air, and Soil Pollution, 125, 201-230.

Morel, J. L. (1997). Bioavailability of trace elements to terrestrial plants. In: Tarradellas, J., Bitton, G. and Rossel, D. (eds.) 1997. Soil ecotoxicology. CRS Press, Pp. 141-176.

Mugoša, B., Đurovi, D., Nedovi-Vukovi, M., c-Labovi, S. B., \& Vrvi, M. (2016). Assessment of Ecological Risk of Heavy 
Metal Contamination in Coastal Municipalities of Montenegro. Inernationlal Journal of Environmental Research and Public Health, 13, 393.

Naser, H. M., Sultana, S., Mahmud, N. U., Gomes, R., \& Noor, S. (2011). Heavy Metal Levels In Vegetables With Growth Stage And Plant Species Variations. Bangladesh Journal of Agricultural Research, 36(4), 563-574.

Nazir, R., Khan,M., Masab, M., Rehman, H. U., Rauf, N. U., Shahab, S., Ameer, N., Sajed, M., Ullah, M., Rafeeq, M., \& Shaheen, Z. (2015). Accumulation of Heavy Metals (Ni, Cu, $\mathrm{Cd}, \mathrm{Cr}, \mathrm{Pb}, \mathrm{Zn}, \mathrm{Fe}$ ) in the soil, water and plants and analysis of physico-chemical parameters of soil and water Collected from Tanda Dam kohat. Journal of Pharmaceutical Science and Research, 7(3), 89-97.

Ogbonna, D. N., Kii. B. L., \& Youdeowei, P. O. (2009). Some physico-chemical and Heavy metal levels in soils of waste dumpsites in Port Harcourt Municipality and Environs. Journal of Applied Science and Environmental Management, 13(4), 65-70.

Opaluwa, O. D., Aremu, M. O., Ogbo, L. O., Abiola, K. A., Odiba, I. E., Abubakar, M. M., \& Nweze, N. O. (2012). Heavy metal concentrations in soils, plant leaves and crops grown around dump sites in Lafia Metropolis, Nasarawa State, Nigeria. Advances in Applied Science Research, 3(2), 780784.

Rhodes, E. R. (1988). Africa - how much fertilizer needed: Case study of Sierra Leone. Fertilizer Research, 17, 101-118.

Smilde, K. W., van Luit, B., \& van Driel, W. (1992). The extraction by soil and absorption by plants of applied zinc and cadmium. Plant and Soil, 143, 233.
Tella, M., Doelsch, E., Letourmy, P., Chataing, S., Cuoq, F., Bravin, M., \& Saint Macary, H. (2013). Investigation of potentially toxic heavy metals in different organic wastes used to fertilize market garden crops. Waste Management, 33, 184-192.

UNFPA (2007). State of world population 2007: Unleashing the potential of urban growth. United Nations Population Fund, $108 p$.

USDA (2003). Heavy Metal Soil Contamination. Natural Resources Conservation Service. United States Department of Agriculture. Urban Technical Note No. 3. September, 2003

WFP (2015). The State of Food Security in Sierra Leone 2015. Sierra Leone Comprehensive Food Security and Vulnerability Analysis (CFSVA). World Food Program.

Wuana, R. A., \& Okieimen, F. E. (2011). Heavy Metals in Contaminated Soils: A Review of Sources, Chemistry, Risks and Best Available Strategies for Remediation, 2011, Article ID 402647, 20p.

Yargholi, B., \& Azimi, A. A. (2008). Investigation of Cadmium absorption and accumulation in different parts of some vegetables. American-Eurasian Journal of Agricultural \& Environmental Sciences, 3(3), 357-364. 